\title{
ІНСТИТУТ СУДОВОЇ ЕКСПЕРТИЗИ І СПЕЦІАЛЬНИХ ЕКОНОМІЧНИХ ЗНАНЬ У ПРАВОВИХ СИСТЕМАХ ЄВРОПИ І США
}

Федчишина В. В.

Стаття присвячена науковому аналізу вивчення правових джерел використання спеціальних економічних знань у встановленні і розслідуванні кримінальних злочинів. Розслідування злочинів усе більш залежить від експертної науки. Збільшення кількості тяжких міжнародних злочинів вимагає тіснішої співпраці між країнами. Дуже важливо, щоб кожній країні були доступні методи експертних досліджень, які застосовуються в інших країнах.

Досліджено теоретичний $i$ практичний досвід співробітниитва із використанням спеціальних економічних знань у правових системах Європи і США. Розкрито основні принципи в роботі судових експертів-економістів.

Ключові слова: судова експертиза, докази, ENFSI, міжнародні мережі судово-експертних установ, спеціальні економічні знання, межі компетенції, судовий експерт-економіст, оцінка висновку експерта-економіста.

Статья посвящена научному анализу изучения правовых источников использования специальных экономических знаний в установлении и расследовании уголовных преступлений. Расследование преступлений все более зависит от экспертной науки. Увеличение количества тяжких международных преступлений требует тесного сотрудничества между странами. Очень важно, чтобы каждой стране были доступны методы экспертных исследований, которые применяются в других странах.

Исследован теоретический и практический опыт сотрудничества с использованием специальных экономических знаний в правовых системах Европы и США. Раскрыты основные принципы работы судебных экспертов-экономистов.

Ключевые слова: судебная экспертиза, доказательства, ENFSI, международные сети судебно-экспертных учреждений, специальные экономические знания, пределы компетенции, судебный эксперт-экономист, оценка заключения эксперта-экономиста.

The article is devoted to the scientific analysis of the study of legal sources of the use of special economic knowledge in the establishment and investigation of criminal offenses at the international level. Creation of international networks of forensic institutions is evidence of the interest of States in the interaction and strengthening of international cooperation in the field of forensic expertise in order to achieve the advanced level of forensic examination and the quality of their compliance with international standards. The investigation of crimes increasingly depends on expert science. Increasing the number of serious international crimes requires closer cooperation between countries. It is very important that every country has access to expert research methods that are used in other countries. International cooperation of expert institutions will facilitate the exchange of experience in innovations. The analysis of normative documents, which regulates the procedure for attracting specialists from other countries for joint conducting of forensic examinations, includes expert committees of leading experts of other countries. Joint expert commissions, in particular, the European Network of Forensic Experts (ENFSI), according to the norms of procedural legislation of Ukraine, also participate in conduct- ing forensic examinations. Changes that have taken place in the economic, social, political and legal spheres of our state, create a real threat to the development of the state, require special attention and increased attention to the issues of qualitative conducting of examinations. The international policy of European integration requires the implementation of international standards of the functioning of legal institutions in the fight against economic offenses in the practice of criminal justice.

The theoretical and practical experience of cooperation with the use of special economic knowledge in the legal systems of Europe and the USA is researched. The basic principles of work of judicial experts-economists are revealed.

Key words: forensic examination, evidence, ENFSI, international networks of forensic expert institutions, special economic knowledge, competency boundaries, judicial expert-economist, assessment of the expert-economist's conclusion.

Постановка проблеми та їі актуальність. Національна судова економічна експертиза не може існувати в межах окремої держави. Забезпечення функції забезпечення правоохоронної діяльності у боротьбі з економічними правопорушеннями неможливе без інтеграції з міжнародною спільнотою.

Ефективному розвитку інтеграційного процесу у галузі судової експертизи різних держав світу сприяє накопичений досвід нормативно-правового регулювання судово-експертної діяльності та реалізація перспективних підходів до використання позитивних новелізацій, нових шляхів і підходів до взаємодії.

Виклад основного матеріалу. У сучасному світі функціонує п'ять систем, які об'єднують (за різними принципами) наукові резерви судово-експертних установ різних держав: європейська, південно-африканська, судово-екологічна, трасологічна й азіатська $[1$, c. 14$]$.

Із опублікованого в 2012 р. рапорту (доповіді) Ради Європи щодо європейської системи оцінки справедливості [2] слідує, що в Європі не погоджено єдині стандарти щодо ролі судових експертів у судочинстві.

Це свідчить про відсутність гармонізації в узгодженні критеріїв визнання допустимості доказів у країнах Європейського Союзу.

На рівні міжнародних правил це врегульовано Конвенцією про надання правової допомоги у кримінальних справах між Державами-членами Європейського Союзу від 29.05.2000 р. [3]., введеною в дію Радою відповідно до статті 34 Договору про Європейський Союз.

У розділі IV «Міжнародне співробітництво в області судової експертизи» (ст. ст. 22, 23, 24) Закону «Про судову експертизу» визначено порядок проведення судової експертизи за дорученням відповідного органу чи особи іншої держави, з якою Україна має угоду про взаємну правову допомогу і співробітництво. Законодавчо встановлено порядок залучення фахівців з інших

Федчишина В. В., 2019 
держав для спільного проведення судових експертиз, i надано право керівникам державних спеціалізованих установ, що проводять судові експертизи, включати до складу експертних комісій провідних фахівців інших держав. Такі спільні експертні комісії здійснюють судові експертизи за нормами процесуального законодавства України [4].

Створення міжнародних мереж судово-експертних установ $\epsilon$ свідченням зацікавленості держав у взаємодії і посиленні міжнародного співробітництва у галузі судової експертизи з метою досягнення передового рівня проведення судових експертиз і відповідності якості ї проведення міжнародним стандартам.

Тому необхідно встановлювати міжнародні наукові зв'язки з установами судових експертиз та криміналістики інших держав, проводити спільні наукові конференції, симпозіуми, семінари, обмінюватися стажистами, науковою інформацією і друкованими виданнями, здійснювати спільні видання в галузі судової експертизи і криміналістики. Міжнародне співробітництво експертних установ сприятиме обміну досвідом в новаціях.

Однак проблематика формування єдиних загальних принципів надання міжнародної правової допомоги [5], створення європейських стандартів у судово-експертній діяльності [6] та підходів до їх оцінки, залишаються невирішеними. Необхідно вирішувати шляхи гармонізації національних принципів судово-експертної діяльності держав у відповідності до міжнародних правових і професійних стандартів. У процесі пошуку критеріїв доцільно максимально враховувати можливий діапазон потенціалу окремих європейських країн - Нідерландів, Німеччини, Франції, Англії та Уельсу, Чеської Республіки, Ісландії, неєвропейських країн (США та Австралії). Важливо, щоб висновок, складений експертами однієі держави, був доказом для іншої. У європейських країнах поняття «експерт» загалом визначається опосередковано, посиланням на відповідні відомчі положення.

Часто статус експерта також визначає відповідний державний орган (наприклад, суд або інший, спеціально призначений) [7].

У більшості країн Європейського Союзу Міністерство юстиції або іншому уповноваженому органу правосуддя (як, наприклад, в Угорщині, Румунії, Сербії та Словенії) або призначається експерт безпосередньо через веб-сайти (як у Данії, Ірландії, Англії та Уельсі) уповноважені присвоювати статус експерта [8, с. 7]. У 10 країнах: в Албанії, Вірменії, Австрії, Бельгії, Хорватія, Естонія, Франція, Нідерланди, Норвегії та Польщі на короткий термін або тільки на термін повноважень вправі суд призначати судових експертів.

Із 1995 року функціонує Європейська мережа судово-експертних установ (ENFSI). У їі складі налічується 64 експертні установи із 36 країн. Це найбільша у світі об'єднана організація судово-експертних установ, що отримала міжнародне визнання. Серед країн, інститути яких входять в європейську мережу, - Вірменія, Австрія, Азербайджан, Бельгія, Болгарія, Великобританія, Угорщина, Греція, Грузія, Данія, Іспанія, Ірландія, Італія, Литва, Латвія, Нідерланди, Норвегія, Польща, Румунія, Росія, Сербія, Словаччина, Словенія, Туреччина, Швеція, Швейцарія тощо. Сьогодні для спеціалізованої діяльності ENFSI діють два постійні комітети: Постійна комісія з якості та компетенції (QCC), яка формує політику щодо забезпечення якості та компетенції; надан- ня порад експертним робочим групам та членам ENFSI і допомагає лабораторіям ENFSI дотримуватися найкращих практик та міжнародних стандартів та Постійний комітет із досліджень та розвитку (RDSC), який розробляє та підтримує стратегію досліджень та розвитку ENFSI: надає поради та інформацію експертним робочим групам і членам ENFSI щодо відповідних тем досліджень та розробок; сприяє спільним дослідженням між лабораторіями на міжнародному рівні; сприяє навчально-тренувальним курсам у спеціалізованих сферах через брокерську діяльність.

Представники ENFSI з метою підтримання гармонізації процедур та методів експертизи здійснюють співробітництво в галузі досліджень та розробок, постійний обмін інформацією та досвідом.

У складі ENFSI діють сімнадцять експертних робочих груп, які з глибокими знаннями та великою сумлінністю досліджують: тваринні, рослинні та ґрунтові сліди; цифрову обробку зображень; ДНК; документи; наркотики; вибухові речовини; відбитки пальців; вогнепальну зброю/ГБР; дослідження пожеж та вибухів; судова інформаційна технологія; аналіз судової експресії мовлення та звуку; почерк; знаки; фарби та скло; аналіз дорожньо-транспортних пригод; текстиль та волосся [9].

Міжнародна політика євроінтеграції зобов'язує втілювати в практику кримінального судочинства міжнародні стандарти функціонування правових інститутів в боротьбі з економічними правопорушеннями. Цьому раніше не приділялася загальноохоплююча і згуртована увага. Експертні робочі групи з проблематики дослідження економічних правопорушень у складі ENFSI відсутні. Однак спеціальні економічні знання потребують взаємопов'язаних глобалізованих знань, і це має велике значення. Це $\epsilon$ ключовою проблемою формалізації і моделювання спеціальних економічних знань.

Однак в Європі немає єдиної позиції щодо цілого ряду наявних питань, які стосуються залучення експерта, порядку і форм надання висновків.

Із 2010 року в Нідерландах як гарантія відповідної компетенції експертів - осіб із спеціальними знаннями функціонує офіційний реєстр експертів (Nederlands Register Gerechtelijk Deskundigen - NRGD, Голландський реєстр судових експертів) [10]. Основна вимога до експертів - високий рівень спеціальних знань визначеної наукової дисципліни і вміння забезпечити якість виданих висновків, етичні та професійні вимоги, пов'язані з такими цінностями, як незалежність, неупередженість і професіоналізм експерта, юридична компетентність [11].

Основним завданням експерта у кримінальному процесі в Німеччині $\epsilon$ співпраця експерта з судом чи прокуратурою за його спеціальними економічними знаннями, які $\epsilon$ основою рішення, або під час вирішення факту доказування, тобто призначений суддею експерт у Німеччині неупереджено виконує функції «помічника суду» в межах предметної компетенції [7].

Дослідження доказів у Франції відбувається під час досудового слідства, тому переважно експертів призначають із офіційних реєстрів, які складаються з двох типів списків: національного списку, який формується касаційним судом і охоплює територію всієї країни, та списку обласних судів. Особи, внесені до офіційного реєстру, гарантуються досвідом професійної економічної діяльності, пов'язаної із спеціалізацією знань [7]. 
В Ісландській судовій системі, яка ґрунтується на роботі професійних суддів, які приймають рішення одноосібно без участі присяжних і без присяжних, експерту-економісту відведено роль «експерта-судді». Під час судового засідання їм відведено місце поряд із професійним суддею. Завдання «експерта-судді» - служити суду своїми спеціальними предметними знаннями, ставлячи правильні запитання учасникам процесу, та давати належну оцінку зібраним доказам [12].

у Чехії інститут судових експертиз $є$ специфічним: експерт-економіст вправі надавати свої послуги всім державним установам - не тільки судам. Однак всі експерти, і експерт-економіст зокрема, повинні утриматися від надання послуг приватним організаціям.

Реєстр експертів у Чеській Республіці ведеться за 128 спеціалізаціями видів знань. За надання замовнику експертом-економістом неправдивого висновку належить компенсація, тому передбачено обов'язкове страхування цивільної відповідальності осіб зі спеціальними знаннями [13].

В Англії та Уельсі експерту-економісту відведено роль свідка-експерта. Його основне завдання - допомагати суду досягти матеріальної істини через надання об'єктивної та неупередженої думки щодо фактів, складених у межах і на основі спеціальних економічних знань [14].

В англійській системі немає офіційних списків судових експертів. Експертами-економістами можуть бути лише досвідчені особи, які достатньою мірою володіють спеціальними економічними знаннями предметної кваліфікації, і загальновизнано як контроль якості роботи експерта, що повинні відповідати науковим критеріям.

Процесуальна позиція експерта в Сполучених Штатах тісно пов'язана зі специфікою загального права. Як і в англійській системі, судовий експерт сприймається як особливий вид свідків у справі - зміст його свідчень $\epsilon$ думкою про відповідні факти у процесі, які повинні забезпечити їх правильне тлумачення.

Ситуація, в якій фахівець у певній галузі спеціальних знань свідчить як свідок, за винятком із правил, встановлених Федеральними правилами доказування (FRE), опитування свідків не може стосуватися їх вражень і думок про факти [15].

Критерії, за якими правило 702 FRE визначає вимоги до експерта: «свідок, який, опираючись на свої знання, навички, досвід, навчання чи освіту може бути кваліфікований як експерт, вправі дати свідчення у формі висновку. Така людина буде допущена тільки в тому разі, якщо «наукові, технічні та інші знання, якими володіє експерт, $\epsilon$ доречними в контексті оцінки відповідних фактів». Це положення визначає порядок залучення експертів - фахівців зі спеціальними знаннями та свідків у кримінальному процесі США. Конкретні особи, щоб представити свої спеціальні знання та діяти у ролі експертів в Сполучених Штатах визначають сторони у суді. Немає офіційних реєстрів експертів, і сторони обирають кандидатів на ринкових умовах. Під час подання заявки, на сайті зазначається одночасно який з п'яти критеріїв, визначених у принципах 702 FRE, відповідає вимогам для кандидата. Рішення про використання спеціальних економічних знань вирішується після голосування, тобто за участю сторін передбачено лише процедуру попереднього оцінювання судом кандидата на свідка [16, с. 3].
Звичайно, думка, сформована експертом, підлягає окремій оцінці із використання фактичних спеціальних знань [17], i, згідно з доктриною, науково підтверджений висновок експерта повинен формуватися точними і надійними методами [18], відповідати загальновизнаному критерію науки [19].

В Австралії немає офіційних реєстрів експертів, і в принципі $\epsilon$ експерти, вказані сторонами. Експерт повинен діяти незалежно [20], і жодним чином не бути пов'язаним та не мати зобов'язань перед учасниками процесу [21]. За положеннями ст. 79 Закону про докази, висновок експерта визнається як доказ, якщо «у експерта $\epsilon$ спеціальні знання, що базуються на підготовці, освіті або досвіді» [22]. Довести, що висновок сформовано на підставі спеціальних знань, і $€$ допустимим доказом, спираючись на прецедентне право австралійських судів, експерт повинен відповідати вимогам щодо обсягу спеціальних економічних знань на основі освіти, додаткового навчання та професійної досвідченості, довівши, що володіє такими знання [23].

Крім того, є чотири принципи загальних правил судових експертів-економістів та їхніх позицій, яких треба дотримуватися під час призначення експертів:

1) експерт повинен мати достатній обсяг спеціальних знань та досвіду, щоб надійно виконувати свої обов'язки;

2) спеціальні знання - межі компетенції, якими володіють експерти.

3) основи правил (принципів надання висновку) експерту треба дозволити більший і найширший доступ до прямих доказів.

4) загальне правило знань - треба оцінювати, чи насправді у конкретній справі потрібні спеціальні знання [24].

В Австралії визнано, що поняття «спеціальні знання» - це фраза недооцінена, що є проблемою, оскільки не має формальних методів оцінки кваліфікації [25]. На підставі чинних правил можна визнавати спеціальні знання без академічної освіти, тобто лише практичний досвід. Тому представники австралійського вчення підкреслюють, що під час проведення експертного економічного дослідження важливим елементом має бути те, чи використання спеціальних знань описано ґрунтовно, так, щоб можна визнати надійним.

Для протидії економічним злочинам важливим $\epsilon$ проведення відповідних наукових досліджень і своєчасний обмін інформацією між практиками та науковцями,і отримання доказів із-за кордону, співробітництва спеціальних служб.

Кримінальне процесуальне законодавство Польщі однозначно не визначає поняття «експерт». Що стосується концепції «експерта», то ст. 193 \$1 Кримінально-процесуального кодексу Польщі зумовлює: якщо викладення обставин, що мають відношення для вирішення справи вимагає спеціальної інформації, то потрібна експертна думка або експерти.

Хоча в кримінальному праві Польщі поняття «спеціальні знання» вже давно використовується, однак визначення терміна немає. Концепцією передбачається, що це знання, які перевищують загальнодоступні знання в межах визначеної діяльності [27]. Тому рівень спеціальних знань визначається належною освітою і професійним досвідом - це ті знання та навички, які виходять за рамки середнього і практичного [28]. Така 

та науково-методичне забезпечення

норма узгоджується зі змістом ст. 195 КПК Польщі, згідно з якою експертом може бути «будь-яка особа, яка має відповідні знання в спеціальній галузі» [29].

Останніми роками розслідування злочинів усе більш залежить від експертної науки. Збільшення кількості тяжких міжнародних злочинів вимагає тіснішої співпраці між країнами. Саме тому дуже важливо, щоб кожній країні були доступні методи експертних досліджень, які застосовуються в інших країнах. Співпраця у рамках цього проекту поширюватиметься на ті галузі, в яких бракує розуміння, де необхідно застосовувати порівняльний метод, де саме необхідне дослідження. Експерти займаються конкретними видами експертної науки: методикою почеркознавства, аналітичними методами порівняння людських голосів, а також інтерпретацією отриманих доказів в ході розслідування кримінальних злочинів.

Висновки. Судова експертиза охоплює велику кількість наукових дисциплін, і багато актуальних проблем експертної науки важко вирішити, використовуючи тільки ресурси в одній країні. Тому міжнародна співпраця дає суттєві переваги її розвитку.

Підтримуючи наукову концепцію видатного польського вченого-криміналіста з дослідження криміналістичної проблематики організованої фінансово-економічної злочинності Хуберта Колецкого, необхідною умовою ефективного виявлення і розслідування економічних правопорушень $\epsilon$ глибокі знання. 3 цією метою доцільно створити Інститут судово-економічних експертиз, і серед основних можливостей використання спеціальних економічних знань визначити проблеми і тематику, зокрема: понятійні питання - дефініцію понять економічних правопорушень, визначення відмінних ознак, склад іï класифікації (типології); визначення діагностичних, прагматичних і майбутніх цілей i направлень їх практичного використання; прагматичні цілі і прагматичне значення криміналістичного аналізу способів здійснення і розкриття окремих видів - категорій, груп, типів економічних правопорушень, а також як основу оптимального формування профілактики і ефективного проведення оперативно-розшукових дій; порядок направлення на судово-економічну експертизу, визначення діапазону можливостей і цілей; особливості експертного дослідження сутності і видів слідів та можливості їх використання в процесі кримінального провадження; визначення причин процесуального затягування і недостатності доказів у кримінальних правопорушеннях щодо економічних правопорушень із погляду криміналістики [30, с. 95, 97].

Міжнародна політика євроінтеграції сприяє запровадженню в Україні позитивного досвіду використання спеціальних економічних знань у встановленні і розслідуванні кримінальних правопорушень, дотримання меж компетенції спеціальних економічних знань і повноважень судового експерта-економіста під час вирішення поставлених завдань, оцінки висновку експерта-економіста як одного із доказів в рамках кримінального провадження.

Враховуючи це, у сучасних дослідників виникає інтерес до теоретичного і практичного досвіду взаємної правової допомоги і співробітництва із використанням спеціальних економічних знань у правових системах Європи і США.

\section{Література}

1. Клименко Н.І. Азіатська мережа судових експертних установ (asian forensic sciences network - afsn). Криміналістичний вісник. 2015. № 1 (23). С. 14-18.

2. Council of Europe, the European Commission for the Efficiency of Justice, European Judicial Systems, 2012. URL: http://euromed-justice.eu/document/ coe-2012-european-judicial-systems-edition-2012-2010-data-efficiency-and-quality-justice.

3. Конвенція про взаємодопомогу в кримінальних справах між державами-членами Європейського Союзу, Заява, Міжнародний документ від 29.05.2000.

4. Закон України «Про судову експертизу» від 25 лютого 1994 р. № 4038-XII, із змінами та доповненнями.

5. Girdwoyń P. Opiniabiegtego w sprawach karnych w europejskim systemie prawnym. Perspektywy harmonizacji, Warszawa, 2011. $71 \mathrm{~s}$.

6. URL: http://clk.policja.pl/clk/wspolpraca/wspolpracamiedzynarodo/centc-419/87639, Europejska-normalizacjabadan-kryminalistycznych-rola-Centralnego-Laboratorium-K. html.

7. Popa G., Necula I. Study on expert status in the European judicial systems. International Journal of Juridical Sciences. 2013. No. 3. $161 \mathrm{~s}$.

8. Keulen B., Kwakman N. Experts and expert register In Europe. The national and the international level. URL: http://legalresearchnetwork.eu/wp-content/uploads/2011/10/ PaperBerendKeulenNicoKwakmanGroningen.doc.

9. URL: http://enfsi.eu/about-enfsi/structure/workinggroups/.

10. Smithuis M., Van Ruth E., Wieles E. Quality control of forensic experts: the complementary role of accreditation and certification. Expertise \& Recht. 2012. Vol. 6. $220 \mathrm{~s}$.

11. Ploscowe M. The expert witness in criminal cases in France, Germany and Italy. Law and Contemporary Problems. 1935. Vol. 2. $508 \mathrm{~s}$.

12. Magnusson S. The use of experts in Icelandic law and procedure. URL: http://www.scandinavianlaw.se/pdf/51-17.pdf.

13. Sobolovic M. Quality analysis of expert witnesses by the course of knowledge society challenges. Juridical Science Series. 2009. No 01 (November), S. 109-118.

14. Huyghe S., Chan A. The evolution of expert witness law under UK and US juris-dictions. URL: http://www.jamsadr.com/files/uploads/documents/gec-newsletter/jamsgec-news-2014-winter.pdf.

15. Rule 701, U.S. Federal Rules of Evidence. December 2013. http://judiciary.house.gov/_cache/files/5334e54f12cc-44b1-a0bc-697e8e29bd15/evidence2013.pdf.

16. Sapir G. Qualifying the expert witness: a practical voir dire. Forensic Magazine. February/march 2007. URL: http: / / www.chm.uri.edu/forensics/courses/Appendix\% 20-\%20forensic\%20science $\% 20 \& \% 20$ expert\%20witness / Voir\%20Dire.pdf.

17. Rager I., Marshall K. Examination of prior expert qualification and/or disqualification (questionable question sunder the rulet of evidence). The Review of Litigation. 2005. Vol. 24/3. 560 s.

18. Brennan M., Dilenschneider D., Levin M., Robinson J. Find in gander searching expert sand their testimony. URL: http://virtualchase.justia.com/ content/finding-and-researching-experts-and-their-testimony.

19. Browne M., Williamson C., Barlacs L. The perspectival nature of expert testimony In the US, England, Korea and France. Connecticut Journal of International Law. 2002-2003. Vol. 55. S. 67-68.

20. Family Court of Australia, The Changing Face of the expert fitness. Discussion Paper 2002. URL: http:// www. familycourt.gov.au/wps/wcm/connect/FCOA/home/ about publications/ Papers/archived/FCOA_pr_changing_face. 
21. Brand J. Practical issues in engaging and adducing expert evidence - an examination of the process and procedure In the Victoria and federal jurisdictions. Victoria University Law and Justice Journal. 2013. Vol. 93. S. 1.

22. URL: http://www.comlaw.gov.au/Series/C2004A00818.

23. Beran R. The role of the expert fitness In the adversarial legal system, Journal of Law and Medicine. 2009. № 17 (1). S. 133-137.

24. Критерії визначено на підставі справи Dasreelpty. Ltd. vs. Hawchair і пізніше майже повторено в EvidenceAct 2008 та інших нормах, що стосуються доказів/

25. Edmond G. Impartiality, efficiency or reliability? A critical responset experte vidence law In Australia. Australian Journal of Forensic Sciences. 2010. № 1-17. http:// njca.com.au/wp-content/uploads/2013/07/Gary-Edmond-Impartiality-EfficiencyOr - reliability-paper.pdf/

26. Grzegorczyk T., Tylman J. Polskie postępowanie karne, Warszawa, 2011. $530 \mathrm{~s}$.
27. Wyrok SN z dnia 15 kwietnia 1976r., sygn. akt II KR 48/76, OSNKW 1976. No 10-11. Poz. 133.

28. Wyrok SN z dnia 23 listopada 1982r., sygn. akt II KR 186/82, OSNPG 1983. No 5. Poz. 59.

29. Waltoś S. Proceskarny-zarys systemu. Warszawa, 2009. $383 \mathrm{~s}$

30. Колецки Х. О некоторых реалиях преступности, криминалистической практики и науки криминалистики в Польше (основные исследовательские вопросы по криминалистическим проблемам современной организованной финансово-экономической преступности в Польше) Сибирский юридический вестник. 2008. № 3 (42). С. 92-97.

Федчишина В. В., кандидат економічних наук, професор кафедри оперативно-розшукової діяльності Університету державної фіскальної служби України 